\title{
Leaf Area Estimation of Garden Boldo From Linear Dimensions
}

\author{
Ana Maria Alves de Souza Ribeiro ${ }^{1}$, Daniel Alves Mundim ${ }^{1}$, Daisy Cristina Martins Mendonça ${ }^{1}$, \\ Karina Tiemi Hassuda dos Santos ${ }^{2}$, Jéssica Sayuri Hassuda Santos ${ }^{2}$, Vinicius de Souza Oliveira ${ }^{1}$, \\ Gleyce Pereira Santos ${ }^{2}$, Luã Víthor Chíxaro Almeida Falcão Rosa², Weslley do Rosário Santana², \\ Omar Schmildt ${ }^{1}$, Edney Leandro da Vitória ${ }^{2}$ \& Edilson Romais Schmildt ${ }^{2}$ \\ ${ }^{1}$ Postgraduate Program in Tropical Agriculture, Federal University of Espírito Santo, São Mateus, ES, Brazil \\ ${ }^{2}$ Departament of Agrarian and Biological Sciences, Federal University of Espírito Santo, São Mateus, ES, Brazil \\ Correspondence: Luã Víthor Chíxaro Almeida Falcão Rosa, Federal University of Espírito Santo, São Mateus, \\ ES, Brazil. Email: luan_chixaro@hotmail.com
}

Received: January 26, 2019

Accepted: March 2, 2019 Online Published: April 15, 2019

doi:10.5539/jas.v11n5p461

URL: https://doi.org/10.5539/jas.v11n5p461

\begin{abstract}
The objective of this work was to determine a mathematical equation using linear measures that allows estimating a leaf area of the specie Plectranthus barbatus Andrews, a plant with medicinal properties popularly known as garden boldo. For this was performed a direct measurement of the leaf blade considering the length (L) along the midrib and the maximum width (W) perpendicular to the midrib of 500 leaves of different specimens and the observed foliar area (OLA), which were obtained by digitized images. A regression study with linear, quadratic, potential and exponential models was performed using a random sample of 400 from the evaluated leaves using OLA as a function of L, W or LW and then obtaining the estimated leaf area (ELA) of each model. From the remaining 100 leaves a validation of the tested models was performed using ELA as a function of OLA in a simple linear regression. From the residues between ELA and OLA the root-square-mean error and Willmot index (d) was obtained and the normality was verified. The parameters used for validation were: statistically linear and angular coefficient equal to zero and one respectively; coefficient of determination closest to the unit; RQME closer to zero; $d$ index closest to the unit; normal distribution of residues. The equation that best represents the estimated leaf area of the garden boldo is ELA $=0.1389+0.6779$ (LW).
\end{abstract}

Keywords: medicinal plant, non-destructive method, Plectranthus barbatus Andrews, regression

\section{Introduction}

The specie Plectranthus barbatus Andrews, commonly known as Boldo-de-jardim, boldo, boldo-do-reino, alum, among others (Lorenzi \& Matos, 2008), belong to Lamiaceae family (synonymy Labiateae), which have about 300 species widely distributed throughout tropical Africa, Asia and Australia, and some are well adapted in Brazil.

P. barbatus Andrews is an herbaceous or sub-shrub, aromatic, perennial, erect plant when young and decumbent after 1-2 years, slightly branched, up to 1.5 meters in height. With leaves opposite, simple, oval of jagged edges, hairy, measuring 5 to $8 \mathrm{~cm}$ long and very bitter taste, flexible even when dry, being thicker and juicy when fresh. Blue flowers arranged in apical racemous inflorescences. It originated in India, probably brought to Brazil in the colonial period (Lorenzi \& Matos, 2008).

Among the utilities of the garden boldo are the ornamental and medicinal properties (Lukhoba, Simmonds, \& Paton, 2006).

The medicinal properties found in this species are possibly related to the presence of diterpenoids, essential oils and phenolic compounds (Abdel-Mogib, Albar, \& Batterjee, 2002). In popular medicine, P. barbatus Andrews is indicated in cases of abdominal colic (Dubey, Srimal, \& Nityanand, 1981), gastrointestinal diseases such as constipation, gastritis, intestinal spasms; hepatic and dental diseases, in addition, to respiratory diseases such as asthma, bronchitis and pneumonia (Lukhoba et al., 2006).

Considering the beneficial effects of $P$. barbatus Andrews, it is important to perform researches on aspects related to the growth, development and propagation of this species. In most of these studies, the knowledge of the leaf area is critical and perhaps the most important characteristic of vegetative growth. Ribeiro, Conceição, 
Aoyama and Furlan (2017) report the existence of several species known as Boldo including of different genera. Concerning the use in popular medicine, Milaneze-Gutierre, Famelli, Capel, and Romagnolo (2007) report that the incorrect botanical recognition of a specie can cause serious consequences such as phytotherapeutic innocuity and poisoning.

The leaves are responsible for important functions in the plant such as interception and absorption of light, photosynthesis, gas exchange and transpiration (Taiz \& Zeiger, 2009). Zhang and Liu (2010) report the influence of leaf area in the light interception, and therefore plant growth and productivity, becoming one of the key traits in ecophysiological and agronomic studies. An easy economical and accurate estimate of the leaf surface area is a recurrent interest of scientists (Pandey \& Singh, 2011), and mathematical equations have been used to determine the leaf area with high accuracy (Carvalho, Bianco, Galati, \& Panosso, 2011). Estimating the leaf area in a plant where the leaves are the most interesting product is very important.

There are several methods to measure with accuracy the leaf area, being classified in direct and indirect methods (Olfati, Peyvast, Shabani, \& Nosratie-rad, 2010). The indirect methods usually involve the use of regression equations, allow for successive evaluations in the same plant and rapidity in these evaluations, preserving the leaves for later studies, as well as not causing damage to plants (Zanetti, Pereira, Sartori, \& Silva, 2017). The regression equations are obtained from modeling studies involving the leaf area observed as a function of length and width measurements of the leaf blade.

Leaf area modeling has been performed for medicinal species such as juazeiro (Zizyphus joazeiro Mart) (Maracajá, Madalena, Araújo, Lima, \& Linhares, 2008), mofumbo (Combretum leprosum Mart) (Candido, Coelho, Maia, Cunha, \& Silva, 2013), Bauhinia monandra Kurz (Schmildt, Schmildt, Alexandre, Fernandes, \& Czepak, 2016), Valerian (Valeriana jatamansi Jones) (Walia \& Kumar, 2017) and boldo (Plectranthus ornatus) (Silva, Pereira, Cabanez, Mendonça, \& Amaral, 2017). However, we did not find in the literature any equation to estimate the leaf area of garden boldo (Plectranthus barbatus Andrews). In this way the objective of this work was to estimate the modeling of the leaf area of this species through the linear dimensions of the leaf blade.

\section{Material and Methods}

The garden boldo samples (Plectranthus barbatus Andrews) were loaned by the Residents Association of Nova Esperança in São Mateus (South Latitude $18^{\circ} 40^{\prime} 32^{\prime \prime}$, West Longitude $39^{\circ} 51^{\prime} 39^{\prime \prime}$ and with an average elevation of $37.7 \mathrm{~m}$ ). The collect of material and measurements were performed on the same day in November 2014. The Köppen weather classification of the region is AW, presenting rain in summer and dry in winter (Alvares, Stape, Sentelhas, Gonçalves, \& Sparovek, 2014).

In the sampling 500 leaves of a population of adult garden plants were collected. In each plant were harvested leaves at all stages of development in the four cardinal points that did not present damage or attack of diseases or plagues as recommended by Oliveira, Silva, Costa, Schmildt, and Vitória (2017). The leaves were harvested, properly packed in plastic bags and quickly transferred to the Laboratory of Plant Breeding of the Postgraduate Program in Tropical Agriculture of the Centro Universitário Norte do Espírito Santo (CEUNES/UFES), where the allometric measurements were performed.

The length (L) and width (W) dimensions of the leaves were measured with a ruler in centimeters. The length was defined as the distance between the insertion point of the petiole in the leaf blade and the opposite end of the leaf and the width as the largest dimensions perpendicular to the axis of the length, as can be seen in Figure 1. The leaf petiole was removed with scissors. With the data of length and width, the product was also determined between $\mathrm{L}$ and $\mathrm{W}\left(\mathrm{LW}\right.$, in $\left.\mathrm{cm}^{2}\right)$. After these measurements the direct measure of the observed foliar areas was determined, $\left(\mathrm{OLA}\right.$, in $\left.\mathrm{cm}^{2}\right)$ using scanned images using the open source Image $\mathrm{J}^{\mathbb{B}}$ Software (Schindelin, Rueden, Hiner, \& Eliceiri, 2015). The 500 leaves were scanned using an $\mathrm{HP}^{\circledR} \mathrm{C} 4280$ multifunctional scanner and the images saved in tif format and 75 dpi resolution. 


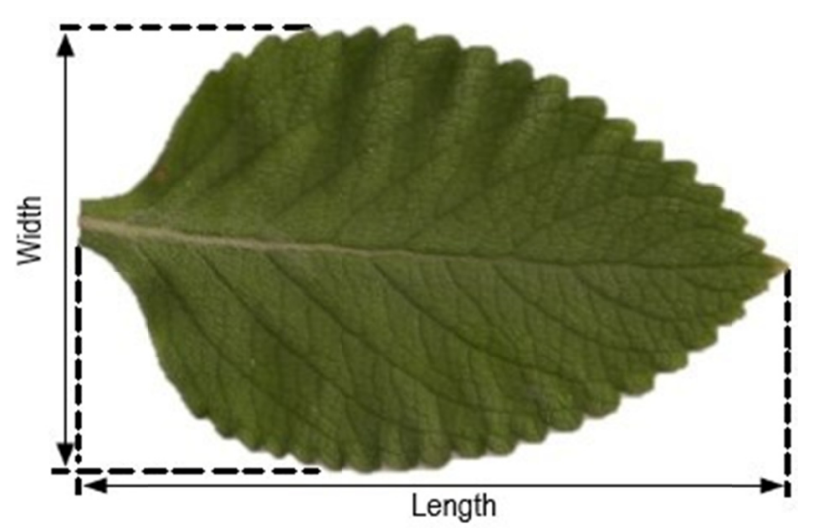

Figure 1. Representation of the predominant format of leaves of Plectranthus barbatus Andrews (L: length measured along the midrib of the leaf blade; W: greatest width of the leaf blade)

Then, among the 500 leaves evaluated, two groups, one with 400 leaves and the other with 100 leaves, were randomly selected, which were used respectively to obtain regression equations and for validation. In both groups for L, W and LW of leaf blade and OLA, measures of central tendency and variability were calculated.

For the estimation of the equations from the 400 leaves sample, linear regression models were used in the parameters (linear and quadratic) and non-linear in the parameters (power and exponential). For these estimates, OLA was used as dependent variable, depending on L, W or LW as independent variables ( $\mathrm{x}$ ), where the estimated leaf area models (ELA) of the models linear, quadratic, power and exponential represented by Equations 1, 2, 3 and 4 respectively.

$$
\begin{gathered}
\text { ELA }=\widehat{\beta}_{0}+\widehat{\beta}_{1} \mathrm{x} \\
\mathrm{ELA}=\widehat{\beta}_{0}+\widehat{\beta}_{1} \mathrm{x}+\widehat{\beta}_{2} \mathrm{x}^{2} \\
\mathrm{ELA}=\widehat{\beta}_{0} \mathrm{x}^{\widehat{\beta}_{1}} \\
\mathrm{ELA}=\widehat{\beta}_{0} \widehat{\beta}_{1}^{\mathrm{x}}
\end{gathered}
$$

Twelve estimated equations, as well as the respective coefficients of determination, were obtained. The parameters $\beta_{0}$ and $\beta_{1}$ were estimated by the method of minimum squares, being performed, early, the linearization of the power and exponential functions.

The validation of the 12 equations of estimated leaf area was performed based on the estimated values by the model (ELA) and the observed values (OLA) of the sample of 100 leaves separated for such finality. First, for each equation of each model, a simple linear regression $\left(y=\widehat{\beta}_{0}+\widehat{\beta}_{1}\right.$ OLA) was adjusted and obtained the coefficient of determination. The simple linear regression was adjusted using the method of minimum squares. The following hypothesis were tested: $\mathrm{H}_{0}: \beta_{0}=0$ versus $\mathrm{H}_{0}: \beta_{0} \neq 0$ and $\mathrm{H}_{0}: \beta_{1}=1$ versus $\mathrm{H}_{0}: \beta_{1} \neq 1$, through Student's t-test at $5 \%$ probability of error. Then, the root-mean-square error (RMSE) was determined (Equation 5) and Willmott's index of agreement (Willmott, 1981) (Equation 6).

$$
\begin{gathered}
\text { RMSE }=\sqrt{\frac{\sum_{i=1}^{\mathrm{n}}\left(\mathrm{ELA}_{\mathrm{i}}-\mathrm{OLA}_{\mathrm{i}}\right)^{2}}{\mathrm{n}}} \\
\mathrm{d}=1-\left[\frac{\sum_{i=1}^{\mathrm{n}}\left(\mathrm{ELA}_{\mathrm{i}}-\mathrm{OLA}_{\mathrm{i}}\right)^{2}}{\sum_{\mathrm{i}=1}^{\mathrm{n}}\left(\left|\mathrm{ELA} A_{\mathrm{i}}-\overline{\mathrm{OLA}}\right|+\left|\mathrm{OLA} \mathrm{A}_{\mathrm{i}}-\overline{\mathrm{OLA}}\right|\right)^{2}}\right]
\end{gathered}
$$

Where, $\mathrm{ELA}_{\mathrm{i}}$ are the estimated values of leaf area from i leaves; $\mathrm{OLA}_{\mathrm{i}}$ are the observed values of leaf area from $\mathrm{i}$ leaves; $\overline{\mathrm{OLA}}$ is the mean of the observed values; $\mathrm{n}$ is the sample size for validation, being $\mathrm{n}=100$, in the present work.

In addition, the normality of the residues for validation was verified obtaining the difference between the ELA and the OLA $A_{i}$, by Shapiro-Wilk test, as suggested by Schmildt et al. (2016).

All the validation statistics were represented graphically, together with the line 1:1, according to Bosco, Bergamaschi, Cardoso, Paula, and Casamali (2012).

The best equation to estimate the leaf area as a function of L, W and LW was chosen by objectives criteria of validation based on the linear coefficient $\left(\beta_{0}\right)$ no different than zero, angular coefficient $\left(\beta_{1}\right)$ no different than one, 
RMSE closer to zero, Willmont index (d) closer to one and residues showing normal distribution. The statistics analysis were performed using R software (R Core Team, 2018) and the graphics using Microsoft Office Excel (Levine, Stephan, \& Szabat, 2017).

\section{Results and Discussion}

The minimum, maximum, mean, standard deviation and coefficient of variation (CV) values of the allometric measures of length (L), width (W), product of the length by the width (LW) and observed leaf area (OLA) of the set of leaves used for both adjust and validation of the equations are shown in Table 1.

The minimum and maximum values of $\mathrm{L}, \mathrm{W}, \mathrm{LW}$ and AFO used in validation showed interval indices with those detected in the leaves used in the equation estimation. This is an interesting confirmation, because according to Levine et al. (2017), using regression model for estimation, the values of the independent variable, which wants to estimate, must not extrapolate the values used in the construction of the regression equation. The mean found for L, in both modeling and validation, was similar to the found by Milaneze-Gutierre et al. (2007).

Table 1. Minimum, maximum, average, standard deviation and coefficient of variation in length along the midrib $(\mathrm{L}, \mathrm{cm})$, maximum width $(\mathrm{W}, \mathrm{cm})$, length of the product by the maximum width $\left(\mathrm{LW}, \mathrm{cm}^{2}\right)$ and observed leaf area $\left(\mathrm{OLA}, \mathrm{cm}^{2}\right)$ of Plectranthus barbatus Andrews leaves

\begin{tabular}{llllll}
\hline Variable & Minimum & Maximum & Average & Standard deviation & Coefficient of variation \\
\hline 400 leaves in modeling & & & & & \\
L & 2.6000 & 14.3000 & 7.9146 & 2.8424 & 35.9136 \\
W & 1.6000 & 8.6000 & 4.6338 & 1.6993 & 36.6726 \\
LW & 4.1600 & 118.6900 & 41.3472 & 27.0400 & 65.4000 \\
OLA & 2.8600 & 80.3200 & 28.1687 & 18.3200 & 65.1500 \\
\hdashline 100 leaves in validation & & & & & \\
L & 2.2000 & 13.6600 & 7.6581 & 2.1355 & 27.8850 \\
W & 1.6000 & 7.8600 & 4.5184 & 1.3931 & 30.8315 \\
LW & 3.5200 & 107.3676 & 37.3926 & 19.6488 & 52.5474 \\
OLA & 3.5200 & 72.78 & 25.4476 & 13.4474 & 52.8436 \\
\hline
\end{tabular}

In relation to variability measured by $\mathrm{CV}$, in the leaves sample used in the adjust of the regression equations, all the allometric measures (L, W, LW and OLA) showed values of CV very high (Table 1), according to Pimentel-Gomes' (2009) criteria. According to Pezzini et al. (2018) the high value of CV is important for models generation, because it can be explained by the collection of leaves in several growth stages, characterizing the growth of the plants. In the 100 leaves used for validation, the variability found in the measures of L, W, LW and OLA was also considered high, according to Pimentel-Gomes' (2009) criteria, showing suitable for this type of analyze, as also stood out Schmildt, Hueso, Pinillos, Stellfeldt, and Cuevas (2017).

The 12 equations obtained for estimated leaf area (ELA), as well as the respective coefficient of determination $\left(\mathrm{R}^{2}\right)$, are shown in Table 2. In general, a good adjust is verified between the OLA and the allometric models, with $\mathrm{R}^{2}$ higher than 0.82 . Among the adjusted equations (Table 2) observe that the highest $\mathrm{R}^{2}$ was obtained using $\mathrm{LW}$ as an independent variable for linear (Equation 3), quadratic (Equation 6) and power (Equation 9) models, showing $\mathrm{R}^{2}$ higher than 0.99 . A good adjust was not verified for exponential model, differently from the observed by Silva et al. (2017) in modeling of another boldo species, the Plectranthus ornatus.

However, a model must not be selected only for the high value of $\mathrm{R}^{2}$, during the modeling, but by the interpretation of all the statistical measures of validation from an independent sample of that used for modeling (Bosco et al., 2012; Fascella, Darwich, \& Rouphael, 2013; Schmildt et al., 2016; Walia \& Kumar, 2017). 
Table 2. Regression models for the estimation of Plectranthus barbatus Andrews leaf area (ELA, $\left.\mathrm{cm}^{2}\right)$ with the respective coefficients of determination $\left(\mathrm{R}^{2}\right)$

\begin{tabular}{lll}
\hline Model & Equation & $\mathrm{R}^{2}$ \\
\hline 1) Linear & $\mathrm{ELA}=-21.5178+6.2779(\mathrm{~L})$ & 0.9454 \\
2) Linear & $\mathrm{ELA}=-20.9930+10.6094(\mathrm{~W})$ & 0.9651 \\
3) Linear & $\mathrm{ELA}=0.1389+0.6779(\mathrm{LW})$ & 0.9978 \\
4) Quadratic & $\mathrm{ELA}=0.5764-0.1080(\mathrm{~L})+0.4024(\mathrm{~L})^{2}$ & 0.9734 \\
5) Quadratic & $\mathrm{ELA}=-4.0672+2.4454(\mathrm{~W})+0.8584(\mathrm{~W})^{2}$ & 0.9821 \\
6) Quadratic & $\mathrm{ELA}=0.1928+0.6746(\mathrm{LW})+0.00003(\mathrm{LW})^{2}$ & 0.9978 \\
7) Power & $\mathrm{ELA}=0.4473(\mathrm{~L})^{1.9446}$ & 0.9733 \\
8) Power & $\mathrm{ELA}=1.2637(\mathrm{~W})^{1.9476}$ & 0.9812 \\
9) Power & $\mathrm{ELA}=0.7189(\mathrm{LW})^{0.9859}$ & 0.9978 \\
10) Exponential & $\mathrm{ELA}=2.5693(1.3092)^{\mathrm{L}}$ & 0.9261 \\
11) Exponential & $\mathrm{ELA}=2.7207(1.5648)^{(\mathrm{W})}$ & 0.9161 \\
12) Exponential & $\mathrm{ELA}=7.0133(1.0277)^{(\mathrm{LW})}$ & 0.8257 \\
\hline
\end{tabular}

The validation made from the sample of garden boldo leaves verified that from the 12 adjusted equations, only those that used LW as an independent variable in the linear, quadratic and power models are suitable, according to the criteria of statistically linear coefficient equal to zero and statistically angular coefficient equal to one (Figure 2). These three equations showed the highest values of $\mathrm{R}^{2}$ and are the same ones that showed the highest values of $\mathrm{R}^{2}$ in modeling (Table 2), as also observed by other researches (Schmildt, Hueso, \& Cuevas, 2014b; Tartaglia et al., 2016). The three equations also showed suitable for use, when it analyzes the other criteria of validation, showing values of RMSE closer to zero and Willmott's index d (1981) closer to one, when it compares with the other obtained equations, and showed a normal distribution of residues. According to Figure 2 , the less adjusted model to the objectives of this work was the exponential, differently from the observed by Silva et al. (2007) for another boldo species (Plectranthus ornatus), which claim to have found the best adjust in exponential model using the width.

In practice, the use of linear model equations based only on one dimension of the leaves is preferable due to simplicity of application, mainly on the field (Tsialtas \& Maslaris, 2005), as performed by Schmildt et al. (2016), who indicated the use of length of leaves in Bauhinia monandra, and by Tartaglia et al. (2016), who indicated the use of width of leaves in canola. However, in relation to garden boldo leaves, none of the models was suitable using only one allometric measure, as can be seen in Figure 2.

These results point out the need of suitable use of the criteria of validation, and must also be interpreted together, as observed by Schmildt, Amaral, Schmildt, and Santos (2014a) in the determination of leaf area in different cultivars of Arabic coffee.

Thus, considering the ease of interpretation, the equation ELA $=0.1389+0.6779(\mathrm{LW})$ (Table 2) is recommended for use, whose criteria of validation are seen in Figure 2. In this figure can be also observed the good adjust of the simple linear equation through straight 1:1. 

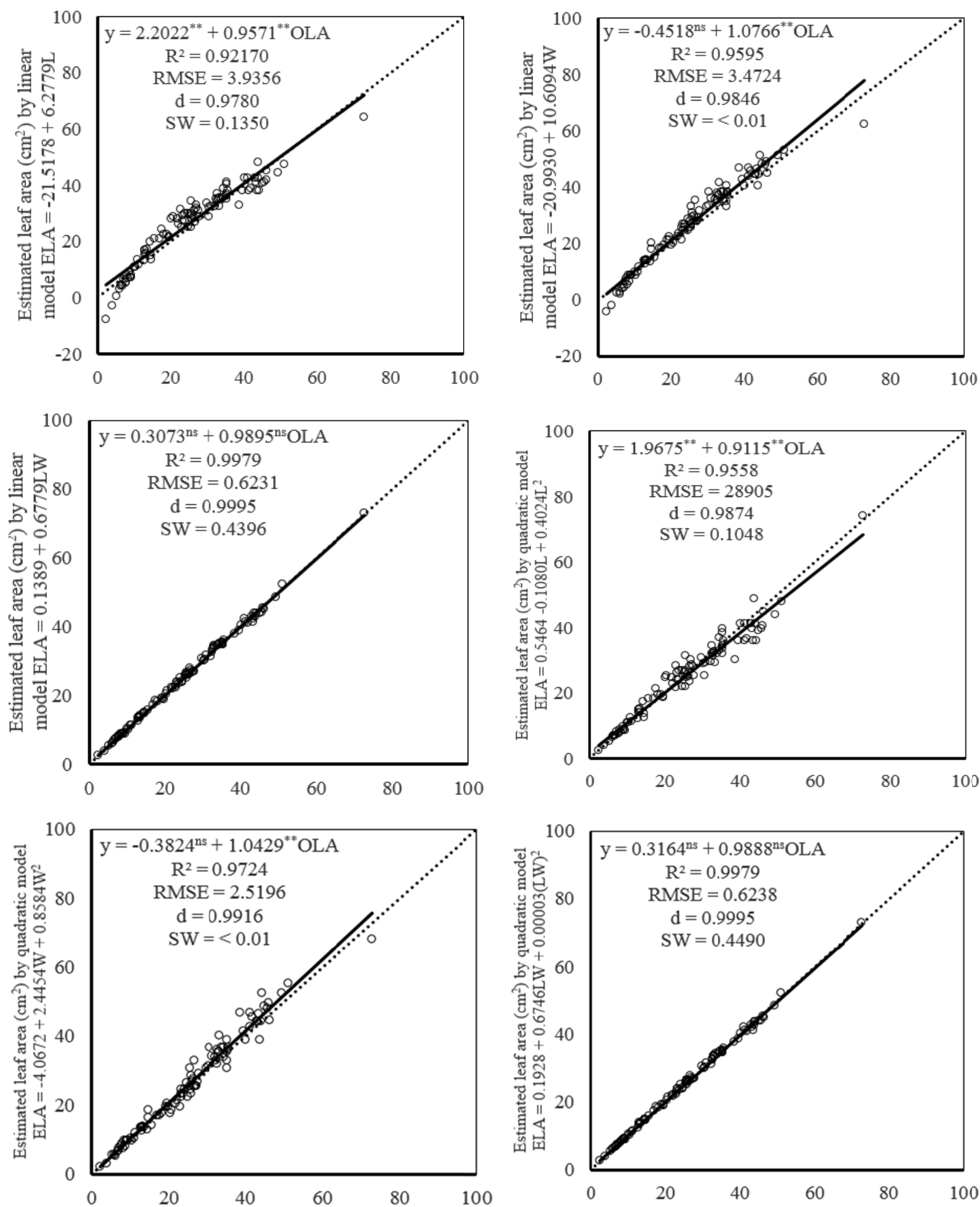

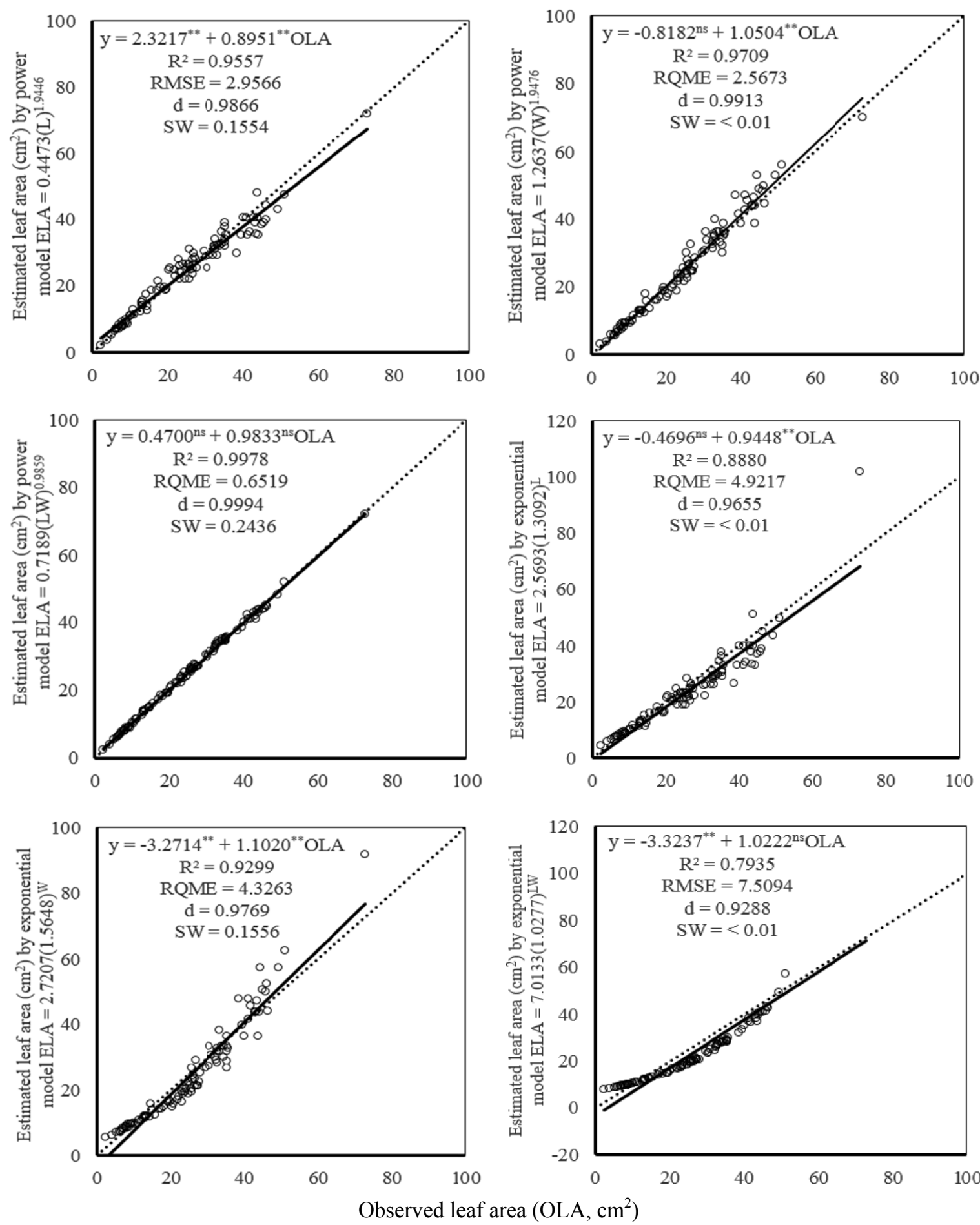

Figure 2. Adjusted equation (y), coefficient of determination $\left(\mathrm{R}^{2}\right)$, root-mean-square error (RMSE), Willmott's index of agreement (d) and p-value of the normality test of the errors by Shapiro-Wilk (SW) obtained from the relationship between estimated leaf area by different models (ELA) and observed leaf area (OLA) of

Plectranthus barbatus Andrews (In adjusted equation $\mathrm{y}=\widehat{\beta}_{0}+\widehat{\beta}_{1}$ OLA, the hypotheses are:

$\mathrm{H}_{0}: \beta_{0}=0$ vs $\beta_{0} \neq 0$ and $\mathrm{H}_{0}: \beta_{1}=1$ vs $\beta_{1} \neq 1$, where, ${ }^{\text {ns }}$ is non-significant $(\mathrm{p}>0.05)$ and ${ }^{* *}$ is significant $(\mathrm{P}<0.01)$ by the $t$ test; dashed line is line 1:1) 


\section{Conclusions}

The leaf area of garden boldo can be estimated with accuracy through non-destructive methods using measures of the dimensions of length (L) and width (W) of leaves in different mathematical models.

The equation ELA $=0.1389+0.6779(\mathrm{LW})$ provided the highest accuracy for the estimation and simplified the calculations.

\section{Acknowledgments}

To CNPq, CAPES and FAPES for the granting of scholarships.

\section{References}

Abdel-Mogib, M., Albar, H. A., \& Batterjee, S. M. (2002). Chemistry of the Genus Plectranthus. Molecules, 7(2), 271-301. https://doi.org/10.3390/70200271

Alvares, C. A., Stape, J. L., Sentelhas, P. C., Gonçalves, J. L. M., \& Sparovek, G. (2014). Köppen's climate classification map for Brazil. Meteorologische Zeitschrift, 22(6), 711-728. https://doi.org/10.1127/0941 $-2948 / 2013 / 0507$

Bosco, L. C., Bergamaschi, H., Cardoso, L. S., Paula, V. A., \& Casamali, B (2012). Seleção de modelos de regressão para estimar a área foliar de macieiras 'Royal Gala' e 'Fuji Suprema' sob tela antigranizo e em céu aberto. Revista Brasileira de Fruticultura, 34(2), 504-514. https://doi.org/10.1590/S0100-29452012 000200024

Candido, W. S., Coelho, M. F. B., Maia, S. S. S., Cunha, C. S. M., \& Silva, R. C. P. (2013). Modelo para estimar a área foliar de Combretum leprosum Mart. Acta Agronómica, 62(1), 37-41.

Carvalho, L. B., Bianco, S., Galati, V. C., \& Panosso A. R. (2011). Determination of Merremia cissoides leaf area using the linear measures of the leaflets. Acta Scientiarum. Agronomy, 33(3), 473-476. https://doi.org/ 10.4025/actasciagron.v33i3.6379

Dubey, M. P., Srimal, R. C., \& Nityanand, S. (1981). Pharmacological studies on oleonol, a hypotensive diterpene from Coleus forskohlii. Journal of Ethnopharmacology, 3(1), 1-13. https://doi.org/10.1016/03788741(81)90010-6

Fascella, G., Darwich, S., \& Rouphael, Y. (2013). Validation of a leaf area prediction model proposed for rose. Chilean Journal of Agricultural Research, 73(1), 73-76. https://doi.org/10.4067/S0718-583920130001 00011

Levine, D. M., Stephan, D. F., \& Szabat, K. A. (2017). Statistics for managers using Microsoft ${ }^{\circledR}$ Excel: Global edition (8th ed.). London: Pearson.

Lorenzi, H., \& Matos, F. J. A. (2008). Plantas medicinais no Brasil: Nativas e exóticas cultivadas (2nd ed.). Nova Odessa: Editora Plantarum.

Lukhoba, C. W., Simmonds, M. S. J., \& Paton, A. J. (2006). Plectranthus: A review of ethnobotanical uses. Journal of Ethnopharmacolgy, 103(1), 1-24. https://doi.org/10.1016/j.jep.2005.09.011

Maracajá, P. B, Madalena, J. A., Araújo E., Lima, B. G., \& Linhares, P. C. (2008). Estimativa de área foliar de juazeiro por dimensões lineares do limbo foliar. Revista Verde de Agroecologia, 3(4), 1-5.

Milaneze-Gutierre, M. A., Famelli, M. C., Capel, L. S., \& Romagnolo, M. B. (2007). Caracterização morfológica dos tricomas foliares e caulinares de duas espécies de Lamiaceae conhecidas popularmente como "falso-boldo". Acta Scientiarum Biological Sciences, 29(2), 125-130. https://doi.org/10.4025/actascibiolsci

Oliveira, P. S., Silva, W., Costa, A. A. M., Schmildt, E. R., \& Vitória, E. L. (2017). Leaf area estimation in litchi by means of allometric relationships. Revista Brasileira de Fruticultura, 39(Special), 1-6. https://doi.org/ $10.1590 / 0100-29452017403$

Olfati, J. A., Peyvast, G. H., Shabani, H., \& Nosratie-Rad, Z. (2010). An estimation of individual leaf area in cabbage and broccoli using non-destructive methods. Journal of Agricultural Science and Technology, 12, 627-632.

Pandey, S. K., \& Singh, H. (2011). A Simple, Cost-Effective Method for Leaf Area Estimation. Journal of Botany, 1-6. https://doi.org/10.1155/2011/658240 
Pezzini, R. V., Cargnelutti Filho, A., Alves, B. M., Follmann, D. N., Kleinpaul, J. A., Wartha, C. A., \& Silveira, D. L. (2018). Models for leaf area estimation in dwarf pigeon pea by leaf dimensions. Bragantia, 77(2), 221-229. https://doi.org/10.1590/1678-4499.2017106

Pimentel-Gomes, F. (2009). Curso de estatística experimental (15th ed.). Piracicaba, SP: Fealq.

R Core Team. (2018). R: A language and environment for statistical computing. R Foundation for Statistical Computing, Vienna, Austria.

Ribeiro, F. F., Conceição, L. O., Aoyama, E. M., \& Furlan, M. R. (2017). Boldo verdadeiro $\times$ boldo falso: Caracterização morfoanatômica foliar. Visão Acadêmica, 18(3), 4-17. https://doi.org/10.5380/acd.v18i3. 54224

Schindelin, J., Rueden, C. T., Hiner, M. C., \& Eliceiri, K. W. (2015). The ImageJ Ecosystem: An Open Platform for Biomedical Image Analysis. Molecular Reproduction and Development, 82(7-8), 518-529. https://doi.org/10.1002/mrd.22489

Schmildt, E. R., Amaral, J. A. T., Schmildt, O., \& Santos, J. S. (2014a). Análise comparativa de equações para estimativa da área foliar em cafeeiros. Coffee Science, 9(2), 155-167.

Schmildt, E. R., Hueso, J. J., \& Cuevas, J. (2014b). Allometric models for determining leaf area of vine 'Sugraone'. Ciência e Técnica Vitivinícola, 29(10), 61-81. https://doi.org/10.17660/th2017/72.1.2

Schmildt, E. R., Schmildt, O., Alexandre, R. S., Fernandes, A. A., \& Czepak, M. P. (2016). Modelos alométricos na determinação da área foliar de Bauhinia monandra Kurz. Comunicata Scientiae, 7(3), 415-419. https://doi.org/10.14295/CS.v7i3.1095

Schmildt, E. R., Hueso, J. J., Pinillos, V., Stellfeldt, A., \& Cuevas, J. (2017). Allometric models for determining leaf area of 'Fino de Jete' cherimoya grown in greenhouse and in the open field. Fruits, 72(1), 24-30. https://doi.org/10.17660/th2017/72.1.2

Silva, S. F., Pereira, L. R., Cabanez, P. A., Mendonça, R. F., \& Amaral, J. A. (2017). T. Modelos alométricos para estimativa da área foliar de boldo pelo método não destrutivo. Agrarian, 10(37), 193-198. https://doi.org/10.30612/agrarian.v10i37.2911

Taiz, L., \& Zeiger, E. (2006). Plant physiology (4th ed.). Sunderland: Sinauer Associates Inc.

Tartaglia, F. L., Righi, E. Z., Rocha, L., Loose, L. H., Maldaner, I. C., \& Heldwein, A. B. (2016). Non-destructive models for leaf area determination in canola. Revista Brasileira de Engenharia Agrícola e Ambiental, 20(6), 551-556. https://doi.org/10.1590/1807-1929/agriambi.v20n6p551-556

Tsialtas, J. T., \& Maslaris, N. (2005) Leaf area estimation in a sugar beet cultivar by linear models. Photosynthetica, 43(3), 477-479. https://doi.org/10.1007/s11099-005-0077-z

Walia, S., \& Kumar, R. (2017). Development of the Nondestructive Leaf Area Estimation Model for Valeriana (Valeriana jatamansi Jones). Communications in Soil Science and Plant Analysis, 48(1), 83-91. https://doi.org/10.1080/00103624.2016.1253723

Willmott, C. J. (1981). On the validation of models. Physical Geography, 2(2), 184-194. https://doi.org/10.1080/ 02723646.1981 .10642213

Zanetti, S., Pereira, L. F. M., Sartori, M. M. P., \& Silva, M. A. (2017). Leaf area estimation of cassava from linear dimensions. Annals of the Brazilian Academy of Sciences, 89(3), 1729-1736. https://doi.org/10.1590/ 0001-376520172016-0475

Zhang, L., \& Liu, X. S. (2010). Non-destructive leaf-area estimation for Bergenia purpurascens across timberline ecotone, southeast Tibet. Annales Botanici Fennici, 47(5), 346-352. https://oi.org/10.5735/ 085.047 .0504

\section{Copyrights}

Copyright for this article is retained by the author(s), with first publication rights granted to the journal.

This is an open-access article distributed under the terms and conditions of the Creative Commons Attribution license (http://creativecommons.org/licenses/by/4.0/). 